\title{
ADULT POSTERIOR URETHRAL VALVES: A CASE REPORT
}

\section{Baduku TS}

Department of Radiology, Kaduna State University, Kaduna, Nigeria

Correspondence: Baduku, TS:

Department of Radiology, Kaduna State University, Kaduna, Nigeria

Email: tokanbabuku@yahoo.com

\section{ABSTRACT}

Posterior urethral valves (PUVs) are now commonly suspected on prenatal ultrasound but still commonly seen postnatally (in Childhood). However, they occasionally present in adolescence and adulthood. A report is made of a 22-year old adult with PUV. Presentation was with symptoms of bladder overflow obstruction. The diagnosis was confirmed by the use of urinary tract ultrasound and micturating cystourethrogram (MCU), the later still being considered as the gold standard.

Key words: posterior urethralvalves, adult, presentation

\section{INTRODUCTION}

Posterior urethral valves are congenital submontanal membranes obstructing the posterior urethra more or less severely. It is the commonest cause of lower urinary tract obstruction in male children ${ }^{2}$, and occurs in approximately 1 in 8,000 live male births. ${ }^{3}$ Late diagnosis of posterior urethral valves during adulthood is uncommon. ${ }^{1}$ Even though this disease condition is rare, it is still believed to be underreported. ${ }^{4}$ When this condition is suspected, cystourethrography, which is still considered the gold standard, is performed.

Presented below is a case of PUV in an adult patient.

\section{CASE REPORT}

K.O is a 22 year Polytechnic student who, for the first time presented at the hospital with a history of straining on micturition, poor urinary stream, dribbling and feeling of incomplete bladder emptying all from childhood. There was no past history of gonococcal infection or urethral injury. Examination revealed a distended urinary bladder. No loin masses were palpated. The external genitalia were within normal limits. An impression of posterior urethral valves was made.The serum creatinine, urea and electrolytes were within normal limits. The urine culture was sterile.

Ultrasound examination showed a grossly distended urinary bladder with a thickened and trabeculated wall. No calculus or sludge was seen within the bladder lumen.The bladder neck was within normal limits. The post-voidal residual urine was significant. Both kidneys s how ed moderate hydrocalycosis but had good corticomedullary distinction. Micturating cystourethrogram confirmed the ultrasound findings of the urinary bladder. There was in addition, marked dilatation of the posterior urethra, giving an "inverted cottage loaf"or figure-of- 8 " sign (see star on figure), with a ring constriction of the bladder base (arrow).There was associated poor urinary stream with underfilling of the anterior urethra.The patient was referred to the urology team for transurethral posterior urethral valve resection which was performed successfully after which the urinary stream significantly improved andthe p r e vi o u s l y not ed hydrocalycosis resolved within two weeks.

\section{DISCUSSION}

Posterior urethral valves occur as early as the fourteenth week of intrauterine life ${ }^{5}$, and are the commonest causes of

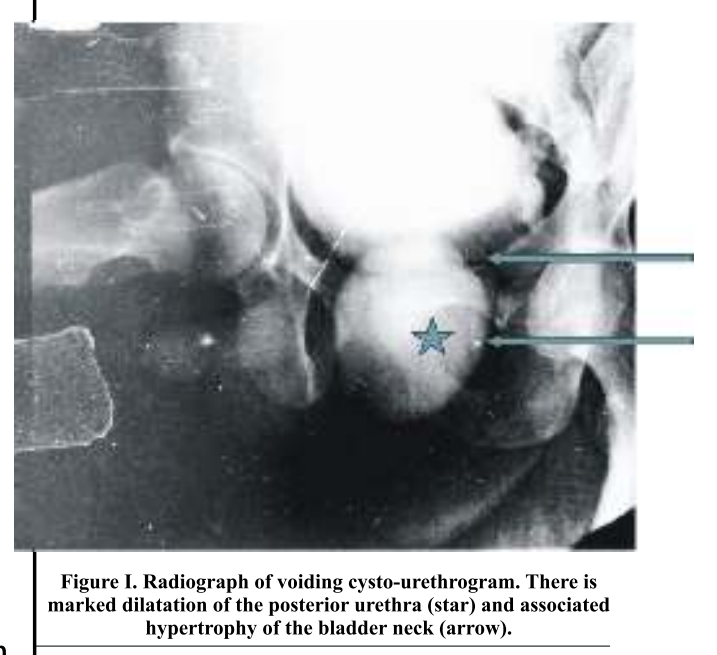

obstruction in the neonates.

The male prostatic urethra is derived from the primitive urogenital sinus which divides into a cranial portion, giving rise to the urinary bladder and the proximal urethra while the caudal portion gives rise to the definitive urogenital sinus. ${ }^{6}$ The theory advanced to explain the embryology of posterior urethral valves is that there are abnormal developments of the Wolfian or Mullerian ducts. ${ }^{7}$ These valves are anatomical folds of mucous membranes on the floor of the prostatic urethra at the level of 
the verumontanum. These valves may be unicuspid or bicuspid, with the latter more common ${ }^{6}$ The paired valvularfolds are fused dorsally, causing partial obstruction by allowing the passage of urine only through a ventral midline slit. The valve can also be in the form of a diaphragm with a tiny hole for the passage of urine.

PUVs have been described as a rare disease but recent studies showed that they are more common than the literature suggests, especially in the developing world. ${ }^{8}$ Hendren also reportedthat many patients never presented to the hospital with symptoms of urinary obstruction but are diagnosed during postmortem. ${ }^{4}$ Improved access to medical care in the $21^{\text {st }}$ century has improved the diagnosis.

PUVs can commonly be diagnosed prenatally by the use of ultrasound. ${ }^{9,10}$ Cases of PUVs that escape detection via prenatal ultrasound may often present after birth with findings such as poor urinary stream, failure to thrive and urinary tract infection. ${ }^{11}$ Older children may present with diurnal enuresis, and severe voiding complaints, such as dribbling and retention, or hematuria. ${ }^{12,13}$ Whether in childhood, adolescent or adult presentation, MCU remains the gold standard for the diagnosis of PUVs., 14

Although posterior urethral valves have been described as an exclusive disease of males ${ }^{15}$ there have been reported cases of posterior urethral valves in the females. ${ }^{16}$ Anterior urethral valves (i.e. in the penile urethra) have also been reported ${ }^{17,18}$, but they are less encountered than the posterior urethral valves.

Posterior urethral valves lead to obstructive uropathy and predispose to infection and urolithiasis. Urinary ascites may result from exudation of urine from the renal pelves. ${ }^{19}$ Children born with urinary ascites die soon after birth $^{11}$. This patient showed the radiological signs of obstructive uropathy with grade four (IV) hydrocalycosiswhich resolved after two weeks of surgical intervention.

In conclusion therefore, the diagnosis of PUVs may be made more frequently if ultrasound of the bladder base is routinely performed in all males with micturating symptoms, followed by MCU when the suspicion is higher.

\section{REFERENCES}

1. Maranya GA. PUV in the adults: report of 2 cases. E. Afr. Med. J. 2004; 81 (8): 430-432.

2. Kousidis GC.Posterior urethral valves. Essentials in Ped. Urol. 2012; 115-124.

3. Nobrega de Jesus CM, Filho JCT, Goldberg J. Late presentation of PUV: 2 case reports. Sao Paulo Med. J. 2008; $126(2):$ 126-127.

4. Hendren HW. Posterior urethral valves in boys: broad clinical spectrum. J. Urol. 1971; 106: 298-307.

5. Jana M, GuptaAK, Prasad KR, Gael S, Tambade VD, Sinha U. Pictorial essay: congenital anomalies of male urethra in children. Indian J. Radiol Imaging 2011;2(1):38-45.

6. Krishnan A, de Souza A, Konijeti R, Baskin LS. The anatomy and embryology of PUVs. J. Urol. 2006; 175: 1214-1219.

7. Hodges SJ, Patel B, Mclorie $\mathrm{G}$, Atala A. Posterior urethral valves. The scientific world J. 2009; 9: 1119-1126.

8. Asinobi AO, Gbadegesin RA, Shittu OB. A review of cases of PUVs seen at the UCH Ibadan (Nig). Pediatric Med. Chir. 2004; 26(6): 430-433.
9. Brown T, Mandell J, Lebowitz RL, Neonatal hydronephrosis in the era of sonography. AJR. 1987; 148:959-163.

10.Ugwu AC, Ahamefula K, Egwu OA Ogwu E, Okonkwo CA,Okafor LC. Patient satisfaction with obstetric ultrasound. Radiol. Technol 2007;79 (2):113118.

11. Dewan PA. Antenatal diagnosis of PUV. BR. J. Urol. 1994; 73 (5): 600-601

12. Agarwal S. Urethral valves. BJU. Intl. 1999; 84:57055708

13. Pereira LP, Umilia PMJ. Jaureguizar E. Initial and long-term management of PUV. World J. Urol. 2004; 22:418-424.

14. deKort LM, Uiterwaal SC, Beek EJ, Jan Nuerelstein RA, Klijn AJ, de Jong TB. Reliability of voiding cystourethrogram to detect urethral obstruction in boys. Urol. 2004; 63 (5):967-971.

15. Young $\mathrm{HH}$, Frontz WA, Baldwin JC. Congenital obstruction of the posterior urethra. J. Urol. 1919; 3: 289-354.

16. Nesbit RM, Mcdonald HP, Busby S. Obstructive valves in the female urethra J. Urol 1964; 79-83.

17. Colabawalla BN. Anterior urethral valves: a case report.J.Urol. 1965; 94: 5863.

18. Tucci S, Franco PB, Melona CAF, Suaid JH, Cologna AJ, Martins ACP. Anterior urethral valves: case report. $\mathrm{J}$ de Pediatra 2003; 79:9194.

19. Ikuerowo SO, Balogun BO, Akintomide TE, Ikuerowo AO, Akinola RA Gbelee H, Esho JA. Clinical and radiological characteristics of Nigerian boys with posterior urethral valves. Pediatr. Surg. Intl. 2008; 24 (7): 825-829. 